\title{
EFEKTIVITAS PENERIMAAN PAJAK BUMI DAN BANGUNAN PERKOTAAN PERDESAAN (PBB-P2) DI KABUPATEN LOMBOK TIMUR TAHUN 2015
}

\author{
Ahmad Nurul Mayadi \\ Jurusan Pendidikan Ekonomi \\ Universitas Pendidikan Ganesha \\ Singaraja Indonesia \\ e-mail:mayadi nurul@yahoo.com
}

\begin{abstract}
Abstrak
Penelitian ini bertujuan untuk mengetahui (1) tingkat efektifitas, (2) hambatan dan (3) solusi dalam penerimaan Pajak Bumi dan Bangunan Perkotaan Perdesaan (PBB-P2) di Kabupaten Lombok Timur. Jenis penelitian ini merupakan penelitian deskriptif. Subjek dalam penelitian ini adalah Kantor Dinas Pengelolaan Pendapatan Keuangan Aset (DPPKA) Kabupaten Lombok Timur. Objek dalam penelitian ini adalah laporan penerimaan PBB-P2 di Kabupaten Lombok Timur tahun 2015. Data dikumpulkam dengan menggunakan metode dokumentasi dan wawancara, dan data dianalisis menggunakan teknik deskriptif. Hasil penelitian menunjukkan bahwa (1) penerimaan Pajak Bumi dan Bangunan Perkotaan Perdesaan pada tahun 2015 sebesar 62,90\% termasuk dalam kriteria kurang efektif. (2) hambatan dalam penerimaan PBB-P2 di DPPKA, masih banyak wajib pajak yang belum memperhatikan kewajibanya untuk membayar PBB-P2, data wajib pajak yang terakhir diterbitkan oleh Kantor Pelayanan Pajak (KPP) tidak cocok dengan sebenarnya dan Penerapan sanksi administrasi yang tidak tegas (3) Solusi yang diambil dalam menanggulangi hambatan penerimaan PBB-2 yaitu meningkatkan kinerja dan profesionalitas pegawai, meningkatkan kordinasi dengan KPP dan pemeriksaan pembukuan secara berkala, melakukan pendekatan dan penindakan sesuai prosedur penagihan kepada wajib pajak yang belum membayar pajak.
\end{abstract}

Kata Kunci: DPPKA, efektifitas, PBB-P2.

\begin{abstract}
Research aims to understand ( 1 ) the rate of effectiveness, ( 2 ) obstacles and ( 3 ) solution in receipt of land and building the tax urban rural areas (PBB-P2) in regency east lombok. The kind of this research is descriptive research. The subject in this research is the office of the management of financial assets ( DPPKA ) east lombok regency. Object in research was report the receipt of PBB-P2 in east lombok regency of 2015. Data were collected by using the documentation and interview method, and data has been analyzed using by descriptive technique.The research results was show that $(1)$ the reception of land and building tax urban rural a 2015 as much as $62,90 \%$ including on the less effective criteria, ( 2 ) obstacles in receipt of PBB-P2 in DPPKA, many taxpayers who have not seen duties to pay PBB-P2 , data taxpayers who last issued by the tax ( KPP) does not match truth and the sanctions imposed administration not firmly ( 3 ) the solution has been Taken in reducing obstacles revenue PBB-P2 the improvement of performance and professionalism employees, increase the coordinates with KPP and examination bookkeeping at regular intervals, doing approach and enforcement accordance with the procedure billing to taxpayers who has not paid the tax yet.
\end{abstract}

Keywords: DPPKA, Effectiveness, PBB-P2. 


\section{PENDAHULUAN}

Pajak merupakan salah satu sumber pembiayaan pembangunan nasional dalam rangka peningkatan kesejahteraan masyarakat. Berkaitan dengan hal tersebut maka penting bagi pemerintah untuk melakukan pengelolaan yang baik terhadap pajak. Penghasilan dari sumber pajak meliputi berbagai sektor perpajakan antara lain diperoleh dari pajak bumi dan bagunan yang merupakan salah satu faktor pemasukan bagi negara yang potensial.

Berdasarkan Undang-Undang Nomor 28 Tahun 2009 tentang "pajak daerah dan retribusi daerah" menyatakan, bahwa daerah diberikan kewenangan untuk mengatur sendiri pajak daerah dan retribusi daerah, dalam rangka memperkuat otonomi daerah, serta memberikan kepastian hukum bagi masyarakat dan dunia usaha. Hal yang penting dalam UU 28/2009 adalah dialihkannya Bea Perolehan Hak atas Tanah dan Bagunan (BPHTB) dan Pajak Bumi dan Bangunan Pedesaan Perkotaan (PBB-P2) manjadi pajak daerah.

Adapun dasar pemikiran dan alasan pokok dari pengalihan PBB-P2 menjadi pajak daerah, yaitu 1), berdasarkan teori, PBB-P2 lebih bersifat lokal (local origin), visibilitas, objek pajak tidak berpindahpindah (immobile), dan terdapat hubungan erat antara pembayar pajak dan yang menikmati hasil pajak tersebut (the benefit tax-link principle). 2), pengalihan PBB-P2 di harapkan dapat meningkatkan Pendapatan Asli Daerah (PAD) dan sekaligus memperbaiki struktur Anggaran Pendapatan dan Belanja Daerah (APBD). 3), untuk meningkatkan pelayanan masyarakat (public Services), akuntabilitas, dan trasparansi dalam pengelolaan PBBP2. 4), berdasarkan praktek di banyak negara, PBB-P2 atau Property Tax termasuk dalam jenis local tex.

Berdasarkan Undang-Undang Nomer 28 Tahun 2009 tentang pajak daerah dan retribusi daerah, pemerintah daerah mempunyai tambahan sumber Pendapatan Asli Daerah (PAD) yang berasal dari daerah pajak. Jenis pajak kabupaten/kota terdiri dari sepuluh jenis pajak, yaitu pajak hotel, pajak restoran, pajak hiburan, pajak reklame, pajak penerangan jalan, pajak mineral bukan logam dan batuan, pajak parkir, pajak air tanah, dan perkotaan.
Dengan diberlakukanya UndangUndang Nomer 28 Tahun 2009 tentang Pajak Daerah dan Retribusi Daerah (PDRD) membawa banyak perubahan dibidang perpajakan, salah satunya terkait dengan mekanisme pemungutan PPB-P2 yang diserah terimakan kepada masingmasing daerah. Tata cara pengalihan PBBP2 sebagai pajak daerah telah diatur dalam peraturan bersama Menteri Keuangan dan Menteri Dalam Negeri Nomor 213/PMK.07/2010 dan Nomor 58 tahun 2010 tentang tahapan persiapan pengalihan PBB-P2 sebagai pajak daerah. Peraturan tersebut kemudian ditindaklanjuti dengan peraturan direktur jendral pajak Nomor PER-61/PJ/2010 tentang tata cara persiapan pengalihan Pajak Bumi dan Bangunan Perdesaan Perkotaan (PPB-P2) sebagai pajak daerah. Pengalihan sepenuhnya penerimaan PBB-P2 kepemerintah kabupaten/kota diharapkan mampu meningkatkan jumlah pendapatan asli daerah. Pada saat PBB-P2 dikelola oleh pemerintah pusat, pemerintah daerah mendapatkan bagian sebesar $64,8 \%$. Namun setelah pengalihan, semua pendapatan dari sektor PBB-P2 akan masuk kedalam kas pemerintah daerah.

Kabupaten Lombok Timur terdiri dari 20 kecamatan dan 96 kelurahaan/desa dengan luas $1.605 .55 \mathrm{~km}^{2}$ dan jumlah penduduk sebesar 688.676 jiwa ini menunjukkan bahwa potensi Pajak Bumi dan Bagunan Perkotaan Perdesaan (PBB-P2) di Kabupaten Lombok Timur cukup besar. Dengan potensi PBB-P2 tersebut maka pemerintah daerah Kabupaten Lombok Timur akan dapat meningkatkan penerimaan daerah, melalui PBB-P2. Pajak Bumi dan Bangunan memiliki potensi besar dalam menambah penerimaan daerah dikarenakan objek pajak ini adalah bumi dan bagunan yang sebagian besar dimiliki masyarakat. Data realisasi penerimaan Pajak Bumi Bangunan Perkotaan dan Perdesaan (PBB-P2) tahun 2014 menunjukan dari Rp. 12.000.000.000 miliar yang ditargetkan hanya bisa terealisasi Rp. 6.685.708.812 miliar dengan persentase $55,71 \%$, tingkat efektivitas penerimaan PBB-P2 Kabupaten Lombok Timur dikatagorikan tidak efektif karena persentase menunjukan dibawah $60 \%$. 
Pemungutan PBB-P2 di Kabupaten Lombok Timur sering kali mendapatkan hambatan, hal ini disebabkan tingkat kesadaran masyarakatnya untuk membayar pajak masih rendah. Selain itu sosialisasi dari kantor Dinas Pendapatan, Pengelolaan Keuangan dan Aset (DPPKA) kepada masyarakat masih rendah. Oleh karena itu hendaknya pemerintah mempunyai program sosialisasi yang tepat untuk meningkatkan kesadaran masyarakat dalam membayar pajak. Serta mengoptimalkan kerja petugas pemungut pajak dalam melayani wajib pajak.

Berdasarkan penjelasan diatas PBB-P2 memiliki peran yang cukup besar bagi kelangsungan dan kelancaran pembangunan di Kabupaten Lombok Timur. Sehingga diperlukan penanganan dan perhatian yang serius dari petugas pemungut pajak dan masyarakat yang tergolong wajib pajak untuk mengoptimalkan pendapatan daerah melalui sektor pajak. Pemungutan di tingkat desa/kelurahan merupakan ujung tombak dari kegiatan pemungutan PBB-P2 di Kabupaten Lombok Timur.

Dalam rangka mengoptimalkan pendapatan dari sektor pajak, aparatur/petugas pajak sangat mempengaruhi tercapai atau tidaknya target pendapatan pajak bumi dan bangunan. Untuk memperlancar penarikan dan pemungut PBB-P2, diperlukan aparatur yang berkualitas. Aparatur yang berkualitas diperlukan dalam proses pemungutan pajak, karena mereka berhubungan langsung dengan wajib pajak. Agar wajib pajak dapat memahami peraturan yang diterapkan oleh pemerintah. Adanya aparatur pajak yang berkualitas dari sektor pajak khususnya PBB-P2 dapat dioptimalkan sehingga pembangunan di daerah yang bersangkutan dapat terlaksana dengan baik.

Dari tahun 2014 sampai dengan tahun 2016 pemerintah Kabupaten Lombok Timur belum mengevaluasi efektivitas penerimaan Pajak Bumi dan Bangunan Perkotaan dan Pedesaan $\mathrm{Hal}$ ini yang melatarbelakangi penelitian mengenai Efektivitas Penerimaan Pajak Bumi dan Bangunan Perkotaan Perdesaan (PBB-P2) di Kabupaten Lombok Timur pada tahun 2015.

\section{METODE}

Jenis penelitian ini merupakan penelitian deskriptif. Tujuan penelitian ini untuk mengukur tingkat efektivitas, hambatan, dan solusi dalam penerimaan Pajak Bumi dan Bangunan Perkotaan dan Pedesaan (PBB-P2) di Kabupaten Lombok Timur tahun 2015. Adapun prosesnya yaitu melakukan pengumpulan data Pajak Bumi dan Bangunan Perkotaan dan Pedesaan (PBB-P2) terlebih dahulu, kemudian data PBB-P2 dianalisis mengunakan analisis deskriptif yang akan menguji dan menilai setiap data yang berhasil dikumpulkan serta memlakukan wawancara untuk mengetahui hambatan dan solusi dalam penerimaan Pajak Bumi dan Bangunan Perkotaan dan Pedesaan di Kabupaten Lombok Timur. subjek dalam penelitian ini adalah kantor DPPKA Kabupaten Lombok Timur, sedangkan objek dalam penelitian ini adalah laporan penerimaan Pajak Bumi dan Bangunan Perkotaan Dan Pedesaan (PBBP2) di Kabupaten Lombok Timur tahun 2015

Jenis data yang digunakan dalam penelitian ini adalah data kuantitatif. Data kuantitatif adalah data yang berbentuk bilangan atau angka dengan menggunakan metode matematis (Griadhi, 2010: 51), Data kuantitatif dalam penelitian ini berupa laporan penerimaan Pajak Bumi Dan Bangunan Perkotaan Pedesaan (PBB-P2) di Kabupaten Lombok Timur tahun 2015. Sumber data yang digunakan dalam penelitian ini berupa data sekunder. Data sekunder dalam penelitian ini yaitu laporan keuangan yang diterima, laporan keuangan yang ditargetkan dalam penerimaan pajak, dan laporan realisasi penerimaan penerimaan Pajak Bumi Bangunan Perkotaan dan Pedesaan (PBB-P2) tahun 2015.

Metode pengumpulan data pada penelitian ini adalah dokumentasi digunakan untuk memperoleh data laporan keuangan berupa realisasi penerimaan PBB-P2 dan data lainnya yang berkaitan dengan penelitian dilakukan dan wawancara tidak terstruktur digunakan dengan pedoman wawancara tidak terstruktur yang bertujuan untuk memperoleh data mengenai kendala yang dialami dalam merealisasikan penerimaan PBB-P2 serta upaya yang telah dilakukan 
p-ISSN : 2599-1418

e-ISSN : 2599-1426

dalam mengatasi kendala tersebut. Teknik analisis data yang digunakan dalam penelitian ini adalah analisis deskriptif. Analisis deskriptif akan menguji dan menilai setiap data yang berhasil dikumpulkan dengan mengunakan rumusan sebagai berikut.

\section{Efektivitas $=\frac{\text { Raalisesi }}{\text { Target }} \times 100 \%$}

Keterangan:

$\mathrm{R}=$ Realisasi penerimaan pajak

$\mathrm{T}=$ Target Pajak .

Kriteria efektivitas bernilai $<60 \%$ maka penerimaan pejak dinyatakan tidak kurang efektif. Kriteria efektivitas bernilai 60-79\%
Jurnal Pendidikan Ekonomi Undiksha

Volume 9 No.1 Tahun: 2017

dinyatakan kurang efektif, kriteria efektivitas bernilai $80-89 \%$ dinyatakan cukup efektif, kriteria efektivitas bernilai $90-100 \%$ dinyatakan efektif, dan jika kriteria efektivitas bernilai > 100\%, maka penerimaan pajak dinyatakan sangat efektif

\section{HASIL DAN PEMBAHASAN}

Jumlah penerimaan Pajak Bumi Bangunan Perkotaan dan Perdesaan (PBBP2) yang diterima oleh Dinas Pendapatan, Pengelolaan Keuangan dan Aset (DPPKA) Kabupaten Lombok Timur seperti yang tertera pada tabel 4.1 berikut.

Tabel 4.1 Laporan penerimaan PBB-P2 Kabupaten Lombok Timur tahun 2015

\begin{tabular}{llllll}
\hline No. & KECAMATAN & \multicolumn{2}{c}{ TARGET } & \multicolumn{2}{c}{ REALISASI } \\
\hline 1 & Selong & $\mathrm{Rp}$ & 1.404 .641 .059 & $\mathrm{Rp}$ & 911.111 .890 \\
\hline 2 & Labuhan Haji & $\mathrm{Rp}$ & 756.811 .786 & $\mathrm{Rp}$ & 402.433 .338 \\
\hline 3 & Sukamulia & $\mathrm{Rp}$ & 365.185 .380 & $\mathrm{Rp}$ & 210.604 .551 \\
\hline 4 & Suralaga & $\mathrm{Rp}$ & 573.915 .860 & $\mathrm{Rp}$ & 291.035 .333 \\
\hline 5 & Sakra & $\mathrm{Rp}$ & 402.770 .135 & $\mathrm{Rp}$ & 300.371 .815 \\
\hline 6 & Sakra Barat & $\mathrm{Rp}$ & 336.718 .398 & $\mathrm{Rp}$ & 255.136 .042 \\
\hline 7 & Sakra Timur & $\mathrm{Rp}$ & 451.268 .175 & $\mathrm{Rp}$ & 352.183 .512 \\
\hline 8 & Keruak & $\mathrm{Rp}$ & 303.024 .004 & $\mathrm{Rp}$ & 202.454 .482 \\
\hline 9 & Jerowaru & $\mathrm{Rp}$ & 522.296 .428 & $\mathrm{Rp}$ & 362.279 .689 \\
\hline 10 & Terara & $\mathrm{Rp}$ & 702.429 .228 & $\mathrm{Rp}$ & 491.006 .926 \\
\hline 11 & Montong Gading & $\mathrm{Rp}$ & 620.102 .831 & $\mathrm{Rp}$ & 389.511 .847 \\
\hline 12 & Sikur & $\mathrm{Rp}$ & 836.035 .202 & $\mathrm{Rp}$ & 505.435 .874 \\
\hline 13 & Masbagik & $\mathrm{Rp}$ & 818.864 .473 & $\mathrm{Rp}$ & 470.783 .407 \\
\hline 14 & Pringgasela & $\mathrm{Rp}$ & 409.174 .584 & $\mathrm{Rp}$ & 298.125 .161 \\
\hline 15 & Aikmel & $\mathrm{Rp}$ & 941.832 .315 & $\mathrm{Rp}$ & 598.950 .030 \\
\hline 16 & Wanasaba & $\mathrm{Rp}$ & 483.089 .080 & $\mathrm{Rp}$ & 232.054 .583 \\
\hline 17 & Sembalun & $\mathrm{Rp}$ & 304.830 .476 & $\mathrm{Rp}$ & 165.810 .793 \\
\hline 18 & Peringgabaya & $\mathrm{Rp}$ & 982.753 .883 & $\mathrm{Rp}$ & 552.513 .771 \\
\hline 19 & Suela & $\mathrm{Rp}$ & 369.395 .892 & $\mathrm{Rp}$ & 208.252 .539 \\
\hline 20 & Sembalia & $\mathrm{Rp}$ & 432.860 .812 & $\mathrm{Rp}$ & 347.458 .279 \\
\hline & JUMLAH & $\mathrm{Rp} \mathbf{1 2 . 0 0 0 . 0 0 0 . 0 0 0}$ & $\mathrm{Rp}$ & $\mathbf{7 . 5 4 7 . 5 1 3 . 8 6 2}$ \\
\hline & & & & &
\end{tabular}

Sumber: Hasil penghitungan lembar observasi

Berdasarkan laporan keuangan DPPKA Kabupaten Lombok Timur di atas, untuk mengukur tingkat efektivitas penerimaan PBB-P2 dengan cara membandingkan antara jumlah realisasi penerimaan dengan jumlah target penerimaan PBB-P2 dengan menggunakan rumus efektivitas sebagai berikut.
Efeletivitas: =

$\frac{\text { Realisasi }}{\text { Target }} \boldsymbol{X} 100 \%$ (Syahelmi, 2008)

Dengan demikian, untuk mengetahui tingkat efektivitas penerimaan PBB-P2 dalam bentuk laporan realisasi penerimaan PBBP2 oleh DPPKA Kabupaten Lombok Timur dapat dilihat pada tabel 4.2. 
Tabel 4.2 Analisis efektivitas penerimaan Pajak Bumi Bangunan Perkotaan dan Perdesaan tahun 2015

\begin{tabular}{|c|c|c|c|c|c|}
\hline No. & KECAMAT AN & TARGET & REALISASI & $\begin{array}{c}\text { PRSENTAS 三 } \\
(\%)\end{array}$ & KRITERIA \\
\hline 1 & Selong & 1.404 .641 .059 & 911.111 .890 & 64,80 & Kurang Efektif \\
\hline 2 & Labuhan Haji & 756.811 .786 & 402.433 .338 & 53,17 & Tidak Efektif \\
\hline 3 & Sukamulia & 365.185 .380 & 210.604 .551 & 57,67 & Tidak Efektif \\
\hline 4 & Suralaga & 573.915 .860 & 291.035.333 & 54,10 & Tidak Efektif \\
\hline 5 & Sakra & 402.770 .135 & 300.371 .815 & 74,58 & Kurang Efektif \\
\hline 6 & Sakra Barat & 336.718 .398 & 255.136 .042 & 75,77 & Kurang Efektif \\
\hline 7 & Sakra Timur & 451.268 .175 & 352.183 .512 & 78,04 & Kurang Efektif \\
\hline 8 & Keruak & 303.024 .004 & 202.454 .482 & 66,81 & Kurang Efektif \\
\hline 9 & Jerowaru & 522.296 .428 & 362.279 .689 & 69,36 & Kurang Efektif \\
\hline 10 & Terara & 702.429 .228 & 491.006 .926 & 68,15 & Kurang Efektif \\
\hline 11 & $\begin{array}{l}\text { IVIontong } \\
\text { Gadin }\end{array}$ & 620 & 7 & 62 & ktif \\
\hline 12 & Sikur & 836.035 .202 & 505.435 .874 & 60,46 & Kurang Efektif \\
\hline 13 & Masbagik & 818.864 .473 & 470.783 .407 & 57,49 & Tidak Efektif \\
\hline 14 & Pringgasela & 409.174 .584 & 298.125.161 & 72,86 & Kurang Efektif \\
\hline 15 & Aikmel & 941.832 .315 & 598.950 .030 & 63,59 & Kurang Efektif \\
\hline 16 & Wanasaba & 483.089 .080 & 232.054 .583 & 48,04 & Tidak Efektif \\
\hline 17 & Sembalun & 304.830 .476 & 165.810 .793 & 54,39 & Tidak Efektif \\
\hline 18 & Peringgabaya & 982.753 .883 & 552.513 .771 & 56,22 & Tidak Efektif \\
\hline 19 & Suela & 369.395.892 & 208.252.539 & 56,38 & Tidak Efektif \\
\hline 20 & Sembalia & 432.860 .812 & 347.458 .279 & 80,27 & Cukup Efektif \\
\hline \multicolumn{2}{|c|}{ RAT A-RATA } & 12.000 .000 .000 & 7.547 .513 .862 & 62,90 & Kurang Efektif \\
\hline
\end{tabular}

Berdasarkan tabel 4.2 tersebut bahwa dari 20 Kecamatan yang berada di Kabupaten Lombok Timur rata-rata $62,90 \%$ menunjukan tingkat penerimaan pajak kurang efektif. Dari 20 Kecamatan di Kabupaten Lombok Timur 11 Kecamatan dengan rata-rata $55 \%$ menunjukan tingkat penerimaan pajak kurang efektif. Adapun kecamatan yang termasuk dalam katagori kurang efektif yaitu Kecamatan Selong, Sakra, Sakra Barat, Sakra Timur, Keruak, Jerowaru, Terara, Montong Gading, Sikur, Pringgasela, Aikmel. Dari 20 Kecamatan di Kabupaten Lombok Timur 11 Kecamatan dengan rata-rata $40 \%$ menunjukan tingkat penerimaan pajak tidak efektif. Adapun kecamatan yang termasuk dalam katagori tidak efektif yaitu Kecamatan Labuhan Haji, Sukamulia, Suralaga, Masbagik, Wanasaba, Sembalun, Peringgabaya, Suela. Dari 20 Kecamatan di Kabupaten Lombok Timur 11 Kecamatan dengan ratarata 5\% menunjukan tingkat penerimaan pajak cukup efektif. Adapun kecamatan yang termasuk dalam katagori cukup efektif yaitu Kecamatan Sembelia. Berdasarkan hasil analisis penerimaan Pajak Bumi dan Bangunan dapat disimpulkan bahwa Dinas Pendapatan, Pengelolaan Keuangan dan Aset Kabupaten Lombok Timur belum berhasil dalam merealisasikan Pajak Bumi dan Bangunan atau belum mencapai dari target Pajak Bumi dan Bangunan Perkotaan Perdesaan yang telah ditentukan.

4.1.1 Kendala yang dihadapi DPPKA Kabupaten Lombok Timur dalam penerimaan Pajak Bumi Bangunan Perkotaan dan Perdesaan tahun 2015.

DPPKA Kabupaten Lombok Timur dalam penerimaan Pajak Bumi Bangunan Perkotaan dan Perdesaan beberapa kendala sebagai berikut.

1. Masih banyak wajib pajak yang belum memperhatikan kewajibannya untuk membayar PBB-P2, serta kurangnya pengetahuan dan pemahaman dalam membayar PBB-P2.

DPPKA Kabupaten Lombok Timur dalam penerimaan PBB-P2 termasuk dalam 
kreteria kurang efektif karena masih mengalami hambatan yang terkait dengan pembayaran atau pelunasan pajak oleh masyarakat .

2. Terdapat data wajib pajak yang terakhir diterbitkan oleh Kantor Pelayanan Pajak (KPP) tidak cocok dengan kondisi yang sebenarnya.

DPPKA Kabupaten Lombok Timur telah berkordinasi dengan KPP namun data wajib pajak yang diterbitkan KPP tidak cocok dengan kondisi yang sebenarnya karena banyak objek pajak yang sudah pindah tangan atau berganti kepemilikan tanpa melapor, terkadang terdapat juga ukuran objek pajak dan alamat wajib pajak tidak diketahui atau pindah alamat. Oleh karena itu petugas yang bertangung jawab harus memeriksa kembali data yang diterbitkan oleh KPP dengan data yang ada pada DPPKA sehingga membuat kinerja pegawai kurang maksimal.

3. Penerapan sanksi administrasi Menurut Undang-Undang Nomor 19 tahun 2000 Pasal 11 yang tidak tegas.

Terkadang sanksi yang diterapkan dalam Undang-undang dinilai terlalu berat dan bersifat memaksa apabila diterapkan sepenuhnya kepada wajib pajak. Oleh karena itu terkadang petugas dilapangan tidak tega untuk menindak wajib pajak yang tidak menyelesaikan kewajiban pajaknya sesuai sanksi yang berlaku. Menurut Undang-Undang Nomor 19 tahun 2000 Pasal 11 menyatakan pelakasanaan dapat dilanjutkan dengan penyitaan sebelum lewat waktu $2 \times 24$ jam setelah surat paksa diberitahukan sebagai mana dimaksud dalam pasal 10. Undang-undang tersebut mengatur jangka waktu sanksi perpajakan yang dikenakan kepada wajib pajak yang pada saat jatuh tempo tidak melakukan pembayaran terhadap hutang pajaknya. Sanksi perpajakan tersebut berupa penyitaan barang yang ditempel atau disegel sita.

4.1.2 Upaya DPPKA Kabupaten Lombok Timur Dalam Mengatasi Kendala Dalam Penerimaan Pajak Bumi dan Bangunan Perkotaan Perdesaan Tahun 2015.

DPPKA Kabupaten Lombok Timur dalam merealisasikan Pajak Bumi dan Bangunan Perkotaan Perdesaan mengalami beberapa kendala, tetapi kendala-kendala tersebut tidak menjadi permasalahan yang serius bagi DPPKA dalam Penerimaan Pajak Bumi dan Bangunan Perkotaan Perdesaan. Dari berbagai kendala yang dialami DPPKA dapat diatasi dengan upaya sebagai berikut.

1. Melakukan pembinaan dan monitoring terhadap wajib pajak yang belum membayar atau melunasi hutang pajaknya.

Melakukan pembinaan dan monitoring terhadap wajib pajak dengan memberikan penyuluhan tentang perpajakan. Penyuluhan perpajakan sarana yang sangat penting dalam rangka meningkatkan kesadaran dan kepatuhan wajib pajak dalam memenuhi kewajiban perpajakannya serta untuk menambah pengetahuan dan pengertian di bidang perpajakan.

2. Meningkatkan kordinasi dengan Kantor Pelayanan Pajak (KPP) dan pemeriksaan pembukuan secara berkala, peremajaan data serta pendataan lebih intensif.

Berdasarkan hasil wawancara yang telah dilakukan kepada Kepala DPPKA Kabupaten Lombok Timur menyatakan akan meningkatkan kordinasi antara DPPKA dengan KPP karena dua lembaga tersebut memiliki hubungan erat satu dengan yang lain mengenai jumlah pajak yang diterima oleh daerah. Pemeriksaan pembukuan secara teratur dan berkala dilakukan untuk memeriksa apakah terjadi suatu perubahan data yang perlu diperbahrui atau tidak. Peremajaan data juga dilakukan setiap 6 bulan sekali karena perubahan objek bisa terjadi setiap saat dan kapan saja. Oleh karena itu pendataan yang lebih intensif terus dilakukan oleh petugas bidang penagihan.

3. Melakukan pendekatan dan penindakan sesuai prosedur penagihan kepada wajib pajak yang belum membayar pajak.

Upaya yang dilakukan untuk mengatasi kendala yang dialami DPPKA Kabupaten Lombok Timur dalam hal sanksi tidak tegas, belum sepenuhnya diterapkan pada wajib pajak yang tidak menyelesaikan kewajibannya. Adapun yang dilakukan DPPKA Kabupaten Lombok Timur sebagai berikut.

a) Selama masih ada itikad baik dari wajib pajak untuk menyelesaikan tunggakan 
pajak pada tahun yang bersangkutan, pembayaran secara akumulatif dapat diberikan kepada wajib pajak mengingat kondisi wajib pajak yang tidak selalu stabil kondisi keuanganya. Hal tersebut menjadi pertimbangan tersendiri bagi bidang penagihan apabila wajib pajak tidak dapat melunasi kewajiban pajaknya sekaligus. sepanjang ada iktikad baik yang ditunjukan oleh wajib pajak untuk melunasi pajaknya secara akumulatif dapat diberikan keringanan yakni wajib pajak dapat membayar tunggakan pajaknya sesuai kemampuan finansial dan akan dibayar secara berangsurangsur. Hal ini dilakukan karena apabila wajib pajak beriktikad buruk tidak melunasi kewajiban pajaknya sampai batas kadaluwarsa maka penerimaan pajak dari sektor PBB-P2 justru semakin menurun dan tidak maksimal.

b) Lebih cermat dalam penerapan sanksi sesuai dengan ijin dari KPP dalam hal penyitaan dan pelelangan objek pajak.

Penerapan sanksi yang lebih tegas dan cermat telah dilakukan bidang penagihan untuk menghindari hal-hal yang tidak diinginkan seperti wajib pajak yang tidak mau membayar ataupun menunggak pembayaranya sampai hampir kadaluwarsa. Selama ini pegawai DPPKA Lombok Timur melakukan prosedur penagihan pajak seperti yang sudah diatur dalam Peraturan Pemerintah Nomor 135 Tahun 2000 menyatakan pelaksanaan sita, penyitaan dilakukan apabila utang pajak tidak dilunasi dalam jangka waktu 2x24 jam sejak tanggal surat paksa diberikan kepada pananggung pajak. Namun selama ini pegawai DPPKA Lombok Timur memberikan jangka waktu 7 hari untuk pananggung pajak melunasi hutang pajaknya dengan catatan pananggung pajak beriktikad baik membayar hutang pajaknya.

\section{Pembahasan}

Dari penelitian yang telah dilakukan penulis melalui metode dokumentasi, dapat dijelaskan tingkat efektivitas penerimaan Pajak Bumi dan Bangunan Perkotaan Perdesaan pada tahun 2015 sebesar $62,90 \%$. Tingkat efektivitas penerimaan Pajak Bumi dan Bangunan Perkotaan
Perdesaan DPPKA Kabupaten Lombok Timur dikategorikan kurang efektif, karena persentasenya menunjukkan 60-79\%. Dengan demikian, penerimaan Pajak Bumi dan Bangunan Perkotaan Perdesaan oleh DPPKA Kabupaten Lombok Timur tahun 2015 belum berhasil dalam merealisasikan Pajak Bumi dan Bangunan atau belum mencapai dari target Pajak Bumi dan Bangunan Perkotaan Perdesaan yang telah ditentukan.

Adapun hasil penelitian yang dilakukan oleh penulis melalui metode wawancara, ditemukan bahwa kendala yang dialami oleh DPPKA Kabupaten Lombok Timur dalam penerimaan Pajak Bumi dan Bangunan Perkotaan Perdesaan adalah, (1 masih banyak wajib pajak yang belum memperhatikan kewajibannya untuk membayar PBB-P2, serta kurangnya pengetahuan dan pemahaman dalam membayar PBB-P2, (2) Terdapat data wajib pajak yang terakhir diterbitkan oleh Kantor Pelayanan Pajak (KPP) tidak cocok dengan kondisi yang sebenarnya, hal ini disebabkan kurangnya koordinasi antara DPPKA Kabupaten Lombok Timur dengan Kantor Pelayanan Pajak. Data wajib pajak yang diterbitkan KPP tidak cocok dengan kondisi yang sebenarnya karena banyak objek pajak yang sudah pindah tangan atau berganti kepemilikan tanpa melapor, terkadang terdapat juga ukuran objek pajak dan alamat wajib pajak tidak diketahui atau pindah alamat, dan (3) Penerapan sanksi administrasi Menurut Undang-Undang Nomor 19 tahun 2000 Pasal 11 yang tidak tegas.

Dari kendala yang muncul di atas dapat diatasi dengan cara; (1) melakukan pembinaan dan monitoring terhadap wajib pajak dengan memberikan penyuluhan tentang perpajakan. Penyuluhan perpajakan sarana yang sangat penting dalam rangka meningkatkan kesadaran dan kepatuhan wajib pajak dalam memenuhi kewajiban perpajakannya serta untuk menambah pengetahuan dan pengertian di bidang perpajakan, (2) meningkatkan kordinasi dengan Kantor Pelayanan Pajak (KPP) dan pemeriksaan pembukuan secara berkala, peremajaan data serta pendataan lebih intensif. Mardiasmo (2006) menjelaskan bahwa kordinasi yang baik akan mampu mendeteksi terjadinya 
inkonsistensi suatu unit kerja dalam pencapaian tujuan organisasi, dan (3) melakukan pendekatan dan penindakan sesuai prosedur penagihan kepada wajib pajak yang belum membayar pajak, selama masih ada itikat baik dari wajib pajak untuk menyelesaikan tunggakan pajak pada tahun yang bersangkutan hal tersebut

\section{SIMPULAN DAN SARAN Simpulan}

Berdasarkan hasil penelitian dan pembahasan maka dapat disimpulkan sebagai berikut.

1) Tingkat efektivitas penerimaan Pajak Bumi dan Bangunan Perkotaan Perdesaan pada tahun 2015 sebesar $62,90 \%$. Tingkat efektivitas penerimaan Pajak Bumi dan Bangunan Perkotaan Perdesaan DPPKA Kabupaten Lombok Timur dikategorikan kurang efektif, karena persentasenya menunjukkan $60-79 \%$ Dengan demikian, penerimaan Pajak Bumi dan Bangunan Perkotaan Perdesaan oleh DPPKA Kabupaten Lombok Timur tahun 2015 belum berhasil dalam merealisasikan Pajak Bumi dan Bangunan atau belum mencapai dari target Pajak Bumi dan Bangunan Perkotaan Perdesaan yang telah ditentukan.

2) Kendala yang dialami oleh DPPKA Kabupaten Lombok Timur dalam penerimaan Pajak Bumi dan Bangunan Perkotaan Perdesaan pada tahun 2015 yaitu (a) masih banyak wajib pajak yang belum memperhatikan kewajibannya untuk membayar PBB$P 2$, serta kurangnya pengetahuan dan pemahaman dalam membayar PBBP2, (b) terdapat beberapa data wajib pajak yang terakhir diterbitkan oleh Kantor Pelayanan Pajak (KPP) tidak cocok dengan kondisi yang sebenarnya, hal ini disebabkan kurangnya koordinasi antara DPPKA Kabupaten Lombok Timur dengan Kantor Pelayanan Pajak. Beberapa data wajib pajak yang diterbitkan KPP ada yang tidak cocok dengan kondisi yang sebenarnya karena banyak objek pajak yang sudah pindah tangan atau berganti kepemilikan tanpa melapor, terkadang terdapat juga ukuran objek menjadi pertimbangan tersendiri bagi bidang penagihan apabila wajib pajak tidak dapat melunasi kewajiban pajaknya sekaligus dan lebih cermat dalam penerapan sanksi sesuai dengan ijin dari KPP dalam hal penyitaan dan pelelangan objek

pajak.

pajak dan alamat wajib pajak tidak diketahui atau pindah alamat, dan (c) penerapan sanksi administrasi Menurut Undang-Undang Nomor 19 tahun 2000 Pasal 11 yang tidak tegas.

3) Upaya yang dilakukan oleh DPPKA Kabupaten Lombok Timur dalam penerimaan Pajak Bumi dan Bangunan Perkotaan Perdesaan tahun 2015 yaitu (a) melakukan pembinaan dan monitoring terhadap wajib pajak dengan memberikan penyuluhan tentang perpajakan. Penyuluhan perpajakan sarana yang sangat penting dalam rangka meningkatkan kesadaran dan kepatuhan wajib pajak dalam memenuhi kewajiban perpajakannya serta untuk menambah pengetahuan dan pengertian di bidang perpajakan, (b) meningkatkan kordinasi dengan Kantor Pelayanan Pajak (KPP) dan pemeriksaan pembukuan secara berkala, peremajaan data serta pendataan lebih intensif, dan (c) melakukan pendekatan dan penindakan sesuai prosedur penagihan kepada wajib pajak yang belum membayar pajak.

\section{Saran}

Berdasarkan hasil penelitian yang telah disimpulkan di atas, peneliti dapat memberikan saran sebagai berikut.

1) Bagi Dinas Pengelolaan Pendapatan Keuangan dan Aset (DPPKA) Kabupaten Lombok Timur

a. DPPKA Kabupaten Lombok Timur lebih meningkatkan penyuluhan kepada masyarakat atau wajib pajak, sehingga wajib pajak dapat membayar pajak tepat pada waktunya dan memberikan pelayanan yang 
mudah dan tidak berbelit-belit kepada wajib pajak.

b. DPPKA Kabupaten Lombok Timur perlu memaksimalkan kinerja para pegawai dan melibatkan seluruh pegawai yang berada pada bidang Pajak Bumi dan Bangunan Perkotaan Perdesaan agar pengumpulan, pendataan, dan pelaksanaan program DPPKA Kabupaten Lombok Timur dapat dilaksanakan secara menyuluruh di Kabupaten Lombok Timur.

2) Bagi Akademik

\section{DAFTAR PUSTAKA}

Diana, Anastasia. PERPAJAKAN

INDONESIA Konsep, Aplikasi dan

Penentuan Praktis. Yogyakarta : Penerbit

Andi.

Erly, Suandy. 2013. Hukum pajak. Jakarta: Salemba Empat

Fidal. 2010. Cara Mudah Praktis

Memahami Masalah-Masalah

Perpajakan. Jakarta: Murai

Kencana.

Griadhi, Nyoman Cakra. 2010. Metodologi

Penelitian IImu Pengetahuan Sosial.

Singaraja: UD.Bali Warna.

Hidayat.1999.Pengertian

Efektivitas.Tersediapada

http://wordpress.com/definisidanpen

ertianefektifitas diaksestanggal

(20Maret 2016).

Mardiasmo.2011. Perpajakan. Yogyakarta: Andi Offset.

Mardiasmo.2013. Perpajakan Edisi Revisi.Yogyakarta. ANDI Yogyakarta

Pasolong, Harbani. 2007. Teori Administrasi Publik Bandung : ALFABETA

Priangga,Maksum.2009. Fungsi-fungsi Dasar Pajak. Tersedia pada www.maksumpriangga.com (Diakses pada tanggal 3 Juni, 2016)

Purwono, Herry.2010. Dasar-dasar Perpajakandan Akuntansi Pajak. Jakarta: Erlangga.

Republik Indonesia.2014. Pedoman Umum Pengelolaan PAJAK BUMI DAN
Bagi peneliti selanjutnya yang ingin melakukan penelitian mengenai penerimaan Pajak Bumi dan Bangunan Perkotaan Perdesaan diharapkan mampu menganalisis subjek yang lebih luas, agar dapat membandingkan efektivitas penerimaan Pajak Bumi dan Bangunan Perkotaan Perdesaan lebih jelas. Selain itu, penelitian ini dapat dikembangkan, karena setiap tahun penerimaan Pajak Bumi dan Bangunan Perkotaan Perdesaan berfeluktuatif dan aturan-aturan yang berlaku dalam Pajak Bumi dan Bangunan Perkotaan Perdesaan terus berkembang.

BANGUANAN PERDESAAN DAN PERKOTAAN. Jakarta

Resmi, Siti.2011. Perpajakan Teori dan Kasus.Buku 1. Jakarta: Salemba Empat

Rimsky, K. Judisseno. 2015. Pajak dan Strategi Bisnis. Jakarta : Gramedia Pustaka Utama

Sugiyono. 2008. Metode Penelitian Kuantitatif, Kualitatif dan R \& B. Bandung : Alfabeta.

Suprapti, Eny. 2006. Perpajakan. Malang : Bayumedia publishing

Syahelmi.2008. Analisis Elastisitas, dan Efektifitas PAD Sumatra Utara Dalam Era Otonomi Daerah. Tesis (tidak diterbitkan). Program Studi Ekonomi Pembanguanan. Sekolah Pascasarjana, Universitas Sumatra Utara Medan.

Tim Penyusun. 2014. Pedoman Penulisan Skripsi dan Tugas Akhir Program Sarjana dan Diploma 3 Universitas Pendidikan Ganesha Edisi Revisi. Singaraja : Undiksha.

Undang-Undang Pajak Lengkap.2015.Jakarta: Mitra Wacana Media

Undang-Undang Republik Indonesia Nomor 28 tahun 2009 tentang Pajak Daerah dan Retribusi Daerah. Jakarta: Pemerintah Republik Indonesia.

Undang-Undang Republik Indonesia Nomor 19 tahun 2000 tentang Penagihan 
Pajak Dengan Surat Paksa. Jakarta:

Pemerintah Republik Indonesia.

Undang-Undang Republik Indonesia Nomor

14 tahun 2002 tentang Pengadilan Pajak. Jakarta: Pemerintah Republik Indonesia.

Waluyo.2005. PERPAJAKAN INDONESIA. Jakarta: Salemba Empat. 